"Innovative development of the management potential at a modern enterprise"

\begin{tabular}{|c|c|c|}
\hline \multirow[b]{2}{*}{ AUTHORS } & \multicolumn{2}{|l|}{ Viktoriia Pysmak (iD) } \\
\hline & \multicolumn{2}{|l|}{$\begin{array}{l}\text { Lidiya Mazhnyk } \\
\text { Tetiana Sigaieva }\end{array}$} \\
\hline ARTICLE INFO & \multicolumn{2}{|c|}{$\begin{array}{l}\text { Viktoriia Pysmak, Lidiya Mazhnyk and Tetiana Sigaieva (2021). Innovative } \\
\text { development of the management potential at a modern enterprise. Economics of } \\
\text { Development, 20(1), 46-55. doi:10.21511/ed.20(1).2021.05 }\end{array}$} \\
\hline DOI & \multicolumn{2}{|c|}{ http://dx.doi.org/10.21511/ed.20(1).2021.05 } \\
\hline RELEASED ON & \multicolumn{2}{|l|}{ Tuesday, 28 December 2021} \\
\hline RECEIVED ON & \multicolumn{2}{|l|}{ Thursday, 04 March 2021} \\
\hline ACCEPTED ON & \multicolumn{2}{|l|}{ Friday, 19 March 2021} \\
\hline LICENSE & \multicolumn{2}{|c|}{$\begin{array}{l}\text { This work is licensed under a Creative Commons Attribution } 4.0 \text { International } \\
\text { License }\end{array}$} \\
\hline JOURNAL & \multicolumn{2}{|l|}{ "Economics of Development" } \\
\hline ISSN PRINT & \multicolumn{2}{|l|}{$1683-1942$} \\
\hline ISSN ONLINE & \multicolumn{2}{|l|}{$2304-6155$} \\
\hline PUBLISHER & \multicolumn{2}{|c|}{ LLC "Consulting Publishing Company "Business Perspectives" } \\
\hline FOUNDER & \multicolumn{2}{|c|}{ Simon Kuznets Kharkiv National University of Economics } \\
\hline$\sigma^{0}$ & 15 & 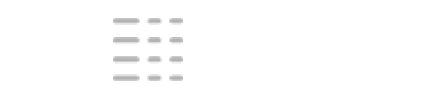 \\
\hline NUMBER OF REFERENCES & NUMBER OF FIGURES & NUMBER OF TABLES \\
\hline 16 & 4 & 1 \\
\hline
\end{tabular}

(c) The author(s) 2021. This publication is an open access article. 


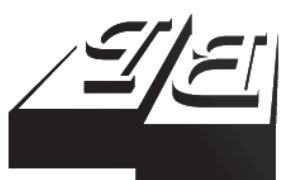

BUSINESS PERSPECTIVES

Publisher

LLC "CPC "Business Perspectives" Hryhorii Skovoroda lane, 10, Sumy, 40022, Ukraine www.businessperspectives.org

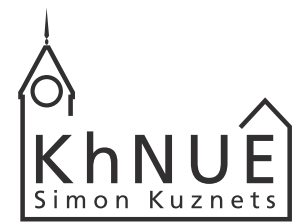

\section{S. KUZNETS KHNUE}

Founder

Simon Kuznets Kharkiv National University of Economics, Nauky avenue, 9-A, Kharkiv, 61166,

Ukraine

http://www.hneu.edu.ua/

Received on: 04th of March, 2021 Accepted on: 19th of March, 2021

Published on: 28th of December, 2021

(c) Viktoriia Pysmak,

Lidiya Mazhnyk,

Tetiana Sigaieva, 2021

Viktoriia Pysmak, Ph.D.

(Economics), Assistant of Professor,

Department of Management,

Logistics and Innovation, Simon

Kuznets Kharkiv National University

of Economics, Ukraine.

Lidiya Mazhnyk, Ph.D. (Economics), Assistant of Professor, Department of Management, Logistics and

Innovation, Simon Kuznets Kharkiv

National University of Economics,

Ukraine.

Tetiana Sigaieva, Ph.D. (Economics), Assistant of Professor, Department of Management, Logistics and Innovation, Simon Kuznets Kharkiv National University of Economics, Ukraine.

\section{(c) (i)}

This is an Open Access article, distributed under the terms of the Creative Commons Attribution 4.0 International license, which permits unrestricted re-use, distribution, and reproduction in any medium, provided the original work is properly cited.

Viktoriia Pysmak (Ukraine), Lidiya Mazhnyk (Ukraine),

Tetiana Sigaieva (Ukraine)

\title{
INNOVATIVE DEVELOPMENT OF THE MANAGEMENT POTENTIAL AT A MODERN ENTERPRISE
}

\begin{abstract}
The development of the national economy and its components in modern conditions is increasingly dependent on technological shifts based on innovation. The ability to form and effectively use potential is becoming a decisive factor in enhancing the competitiveness and development of enterprises. The development of managerial capacity will allow enterprises to adapt quickly to new environmental conditions and make effective management decisions. With the transformation of the economic system towards social orientation, there is a transition from outdated forms of enterprise potential management to a new vision of the quality of management potential.

Basic approaches to assessing the quality of management potential in its innovative development were formed. The main features of the innovative development of managerial potential were identified. The main features of the development of innovative management potential were determined. A basic structure for management potential innovative development measures was proposed, which regulates that a company's policy in the field of improving the efficiency of management capacity is a subordinate element of the general strategy of an enterprise, but at the same time it is necessary to monitor the balance between economic performance and social justice.
\end{abstract}

Keywords

JEL Classification innovation, management potential, innovative development, modern enterprise, development efficiency

В. О. Письмак (Україна), Л. О. Мажник (Україна), Т. Є. Сігаєва (Україна)

\section{ІННОВАЦІЙНИЙ РОЗВИТОК УПРАВЛІНСЬКОГО ПОТЕНЦІАЛУ СУЧАСНОГО ПІДПРИЕМСТВА}

\section{Анотація}

Розвиток національної економіки та їі складників у сучасних умовах все більше залежить від технологічних зрушень на базі інновацій. Уміння формувати й ефективно використовувати потенціал стає вирішальним фактором підвищення рівня конкурентоспроможності та розвитку підприємств. Розвиток управлінського потенціалу дозволить підприємствам швидко адаптуватися до нових умов зовнішнього середовища та приймати ефективні управлінські рішення. В умовах трансформації економічної системи у напряму соціальної орієнтації, відбувається перехід від застарілих форм управління потенціалом підприємства до нового бачення якості управлінського потенціалу.

В дослідженні були сформовані основні положення щодо інноваційного розвитку управлінського потенціалу підприємства, з урахуванням складової управлінського персоналу. Виокремлено основні особливості інноваційного розвитку управлінського потенціалу. Були запропоновані основні заходи інноваційного розвитку управлінського потенціалу сучасного підприємства, сутність яких полягає в тому, що політика підприємства в галузі підвищення ефективності управлінського потенціалу є підпорядкованим елементом загальної стратегії підприємства, але постійно необхідно вести контроль щодо дотримання балансу між економічними результатами діяльності та соціальною справедливістю.

\section{Ключові слова}

Класифікація JEL інновація, управлінський потенціал, інноваційний розвиток, сучасне підприємство, ефективність розвитку

M21, L29, M50, O15 


\section{INTRODUCTION}

The problem of efficient enterprise resource provision primarily depends on the enterprise management system and the expertise of its executives. Approaches to the formation of an effective management system have been studied in many works of modern researchers; a summary of the research results shows that traditional methods of human resource management in a modern dynamically developing enterprise are ineffective and create a certain mechanism that prevents the development processes of managerial personnel. Traditional human resource management methods are ineffective within the framework of a modern dynamic enterprise and create a certain mechanism that prevents the development processes of management personnel. Thus, the quality of management activity is one of the primary factors that determine the ability of the enterprise to accomplish the tasks it sets.

Approaches to the creation of an effective management system have been studied in many works of modern scientists, Generalization of research results indicates that traditional methods of human resource management in a modern dynamically developing enterprise are ineffective and create a certain mechanism that hinders the processes of managerial personnel development.

\section{LITERATURE REVIEW}

The majority of research works published in the modern economic literature in Ukraine and abroad are devoted to the research and elaboration of the methodology and enterprise human resources, financial and innovation potential evaluation methods. The works by Ander (2003), Armstrong (2008), Bilorus (2018), Ghruzynova (2010), Kibaljuk (2006), Ladunka (2011) and Sabadyrjova (2010) are devoted to the issue of forming and distinguishing the enterprise management potential as well as management potential innovative development.

Pysarenko (2020) considers innovation potential as unused, latent possibilities of accumulated resources that can be put into action to achieve the goals of an economic subject. The innovation potential of an organization is also considered as a measure of readiness to perform the tasks that ensure the achievement of the set innovation goal Ghruzinova (2010).

Issues related to the measurement of management, human resources, and financial potential have been researched to a much lesser extent. However, researches (Bilorus, 2018; Vorsovskyi, 2007; Ladunka, 2011; Sabadyrova, 2010) highly evaluate the role of these factors, analyses the practices and management technologies of innovative enterprises, and prove their impact on the efficiency of innovative activity of the enterprise.

\section{AIMS}

The aim of the article is further development and methodological support of the formation for management potential innovative development at a modern enterprise, which takes into account the component of management potential and reveals the essence of basic structure of management potential innovative development measures.

\section{RESULTS}

Summary of practical experience in recent years has led to the following conclusion about managerial capacity: the foundation of the production process is human activity and the competitiveness of any enterprise is determined by the potential of its personnel.

The keen interest to the notion of "management potential" resulted in two substantially different approaches: resource-based and factor approaches. On the one hand, the resource-based approach defines management potential through management resources studied from the standpoint of quantitative and qualitative criteria. On the other hand, adherers of the factor approach define management potential as a peculiar form of the human factor, i.e., human management capability. In our opinion, management potential must reflect the complex of learning, labor and psychophysiological resources of a manager, which can provide the highest level of management activity. 
The consistent trend among managers of the leading Ukrainian enterprises as to perceiving management potential as the basis for production is being studied. In this regard, the notion of "management potential" becomes the subject of the scholarly discussion.

The notion of "potential" was derived by the economic science from physics (lat. "potentia» - power) where it rei fers to a certain quantity of energy accumulated by the system and which can be implemented in work (Vorsovskyi, 2007). The Explanatory Dictionary by Ozhegov defines potential as a physical quantity, which characterizes the force field at the given point, or the electric charge or quantity, which determines the energy store of the body at a certain point of the force field (electric, magnetic etc.) (Busel, 2016). In everyday life, the notion "potential" refers to the available means, supplies, certain sources, which can be applied in order to achieve a particular aim.

In the enterprise management theory, the economic activity is invariably connected directly with human resources, i.e. with people. However, from the standpoint of management, labor bears the name of management activity due to the presence of a set of characteristic features such as the subject of labor, outcome and its effectiveness.

Increased interest to the notion of "management potential" resulted in two completely different approaches to its interpretation. On the one hand, management potential refers to certain resources of an enterprise under study in respect of unity. On the other hand, management potential is a certain form of human factor perceived as a capacity for management activity. An of the abovementioned definitions management potential presupposes a set of certain learning, psychic and personal traits of the enterprise human resources, which provide for the highest qualitative level of management and optimal performance of professional functions under the current conditions.

Thus, the planned economy was based on the state ownership and human resources were not considered an "article of value". The personnel policy of that time was characterized by the three distinguished personnel reproduction phases: production, division and employment. Upon that, production presupposed human resources formation, training, retraining and further development, division presupposed their reallocation across fields of activity and employment was skilled labour force implementation. Hence, the planned economy focused on the distribution relationship, so quantitative and not qualitative personnel reproduction parameters are characteristic of this system. However, the command economy had a great advantage of constant personnel management planning process, which provided sustainable system development (Hruzinova, 2010).

Thus, in order to form the modern theoretical basis, it is worth providing the analysis of the former management potential formation system and assessing the situation with respect to the process of transition to the market economy (Figure 1).

\begin{tabular}{|c|c|c|}
\hline \multicolumn{3}{|c|}{ Economic System Type } \\
\hline Planned Economy & Market Economy & Socially-Oriented Economy \\
\hline \multicolumn{3}{|c|}{ Government Control of Enterprise Recruitment Policy } \\
\hline $\begin{array}{l}\text { Government regulation and control of } \\
\text { recruitment policy }\end{array}$ & $\begin{array}{l}\text { Absence of maximum limitation of } \\
\text { government regulation and control of } \\
\text { recruitment policy }\end{array}$ & $\begin{array}{l}\text { Partial government regulation and control of } \\
\text { recruitment policy }\end{array}$ \\
\hline \multicolumn{3}{|c|}{ Functional Tasks of Personnel Management System } \\
\hline $\begin{array}{l}\text { System of personnel training, } \\
\text { retraining and development, audit and } \\
\text { reporting, personnel appraisal, social } \\
\text { functions }\end{array}$ & $\begin{array}{l}\text { Continuous system of personnel training, } \\
\text { retraining and development, system of } \\
\text { motivation, bonuses, labour potential } \\
\text { assessment, personnel marketing }\end{array}$ & $\begin{array}{l}\text { Continuous system of personnel training, retraining } \\
\text { and development, system of motivation, bonuses, } \\
\text { labour potential assessment, personnel marketing, } \\
\text { personnel development, quality of work life and } \\
\text { social security }\end{array}$ \\
\hline \multicolumn{3}{|c|}{ Requirements to Management Potential } \\
\hline Political orientation & Economic feasibility orientation & Economic and social feasibility orientation \\
\hline
\end{tabular}

Figure 1. Interdependence of the economic system type and requirements to the management potential 
This was followed by the transition from the planned economy to the market relations, which caused separation of one of the personnel policy functions - division. Due to the fact that within the transition to the market economy the guiding principle was making maximum profit, personnel development generally lacked attention.

Analysis of the situation in 2013-2019 in the innovation field of the state enables to conclude that in absolute terms the increase in total expenditure on the innovative activity does not have a considerable impact on the continual upward trend in the development of enterprises involved in the innovative activity.

Official statistics confirm that the issues in the development of innovative activities of enterprises lie in the amount of funds and directly in the sources of funding, which are declining, but there remain enterprises that continue to innovate and contribute to the development of the economy, but at the same time it should be remembered that the vast majority of innovation is carried out by enterprises at their own expense.

The main priority for the financial and economic activities of domestic enterprises, which develop under the requirements of the time, must be timely management potential innovative development process because it covers in its essence the substantial percentage of capacity reserve.

Table 1. Enterprise Innovative Activity and Their Expenditure on Innovations in 2013-2020

Source: The table was built by the author based on the data (State Statistics Service of Ukraine, n.d.; Pysarenko, Kvasha, Rozhkova, \& Kovalenko, 2020).

\begin{tabular}{|c|c|c|c|c|c|c|}
\hline \multirow[b]{2}{*}{ Year } & \multirow{2}{*}{$\begin{array}{l}\text { Share of the number of } \\
\text { industrial enterprises } \\
\text { implementing innovations } \\
\text { in the total number of } \\
\text { industrial enterprises, } \%\end{array}$} & \multirow[b]{2}{*}{$\begin{array}{c}\text { Total } \\
\text { Expenditure, } \\
\text { mln UAH }\end{array}$} & \multicolumn{4}{|c|}{ Of which are funded from, mIn UAH } \\
\hline & & & Equity funds & State budget & $\begin{array}{l}\text { Foreign } \\
\text { investors }\end{array}$ & $\begin{array}{l}\text { Other } \\
\text { resources }\end{array}$ \\
\hline 2013 & 13.6 & $9.562,6$ & $6.973,4$ & 24.7 & $1.253,2$ & $1.311,3$ \\
\hline 2014 & 12.1 & $7.695,9$ & $6.540,3$ & 344.1 & 138.7 & 672.8 \\
\hline 2015 & 15.2 & $13.813,4$ & $13.426,8$ & 96.6 & 179.5 & 110.5 \\
\hline 2016 & 16.6 & $23.229,5$ & $22.036,0$ & 179.0 & 23.4 & 991.1 \\
\hline 2017 & 14.3 & $9.117,5$ & $7.704,1$ & 227.3 & 107.8 & $1.078,3$ \\
\hline 2018 & 15.6 & $12.180,1$ & $10.742,0$ & 639.1 & 107.0 & 692.0 \\
\hline 2019 & 13.8 & $14.220,9$ & $12.474,9$ & 556.5 & 42.5 & $1.147,0$ \\
\hline 2020 & 14.9 & $14.406,7$ & $12.297,7$ & 279.5 & 125.3 & $1.704,2$ \\
\hline
\end{tabular}

The Table 1 shows that main constituents of total expenditures on innovative activity are equity funds, state budget, foreign investors and other resources. It is seen that each year equity funds are the biggest source of contribution in innovative activity of enterprises. The situation with financing from the state budget is changing to worse. There is a lack of state budget financial support. The share of foreign investors in total expenditure is increasing while it has extremely dropped in 2016. Since 2014 Ukraine doesn't meet a lot of investments from foreign countries. Such situation takes place due to unstable situation in Ukraine. The main reasons of such awareness' are military conflict on the East of Ukraine and ineffectual fight against corruption.

The results of the analysis of the dynamics of the indicators show that the average share of the number of industrial enterprises implement in innovations in the total number of industrial enterprises for period between 2013 and 2020 is at $14.52 \%$. It means that only $14.52 \%$ of Ukrainian industrial enterprises are involved in innovation activity. It is important to understand that all innovative activities of enterprises are mainly based on equity funds. There is the lack of financing from other sources. For example, it is possible to build a diagram of total expenditure on innovative activity in 2020 based on Table 1. It will show the difference between sources of innovative activity financing.

It is clear that in the most cases expenditure on innovative activity are funded by equity funds. Foreign investments have been decreasing since 2014. Most of Ukrainian enterprises have not enough resources to invest them in innovative activity, so they have to attract them from the state budgets and foreign investors. 


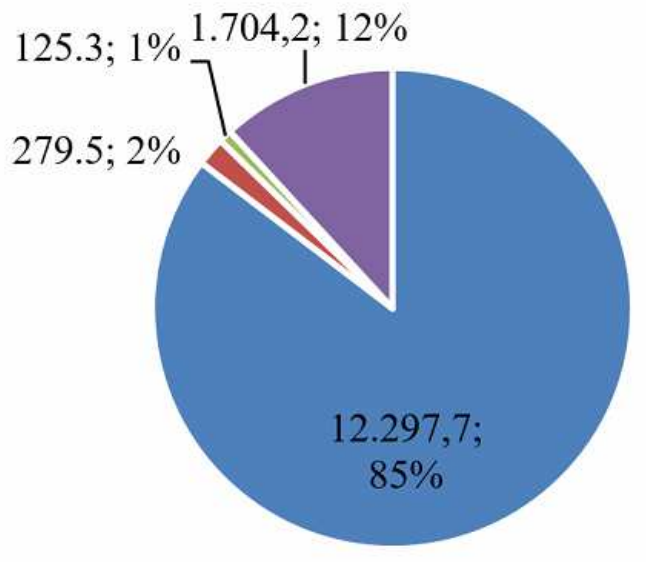

- Equity funds

- State budget

- Foreign investors

- Other resources

Source: Based on Table 1.

Figure 2. Foundation of expenditure on innovative activity in 2020, mln UAH
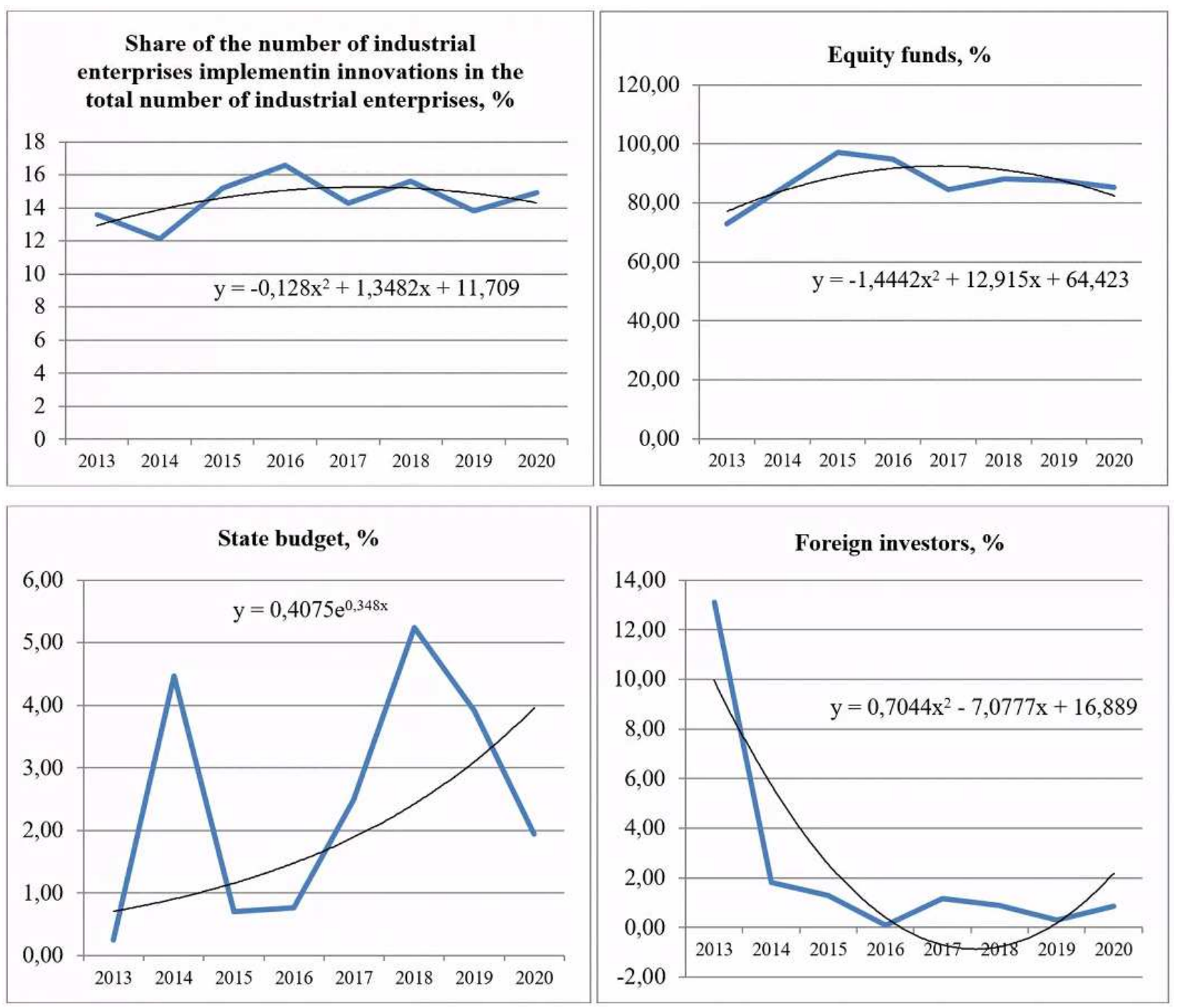

Source: Based on Table 1.

Figure 3. Graphic representation of the impact of financing parameters in terms of its individual sources on the dynamics of the total expenditure of domestic enterprises on innovation for the period 2013-2020 
A more detailed analysis of the dynamics of the total expenditure of domestic enterprises on innovation (Table 1) allowed to determine the impact of funding parameters in terms of its individual sources on the achieved result. The parameters of the impact in graphical form are presented in Figure 3.

The main cause of such a low level of involving is that financing of scientific research in Ukraine belongs to Fourth wave of innovation. Electronics and microelectronics, automotive industry, non-ferrous metallurgy, oil refining, synthetic polymer materials are the common direction of innovative activity in Ukraine (57.9\% of investments). For example, United States of America, one of the strongest economies of the world, invest capital in development of technologies of the Sixth wave of innovation (nano- and biotechnology, nano- energy and etc.). Foreign investors and huge investment companies do not want to invest their capital to the obsolete production areas. That is why we have such a low level of enterprises involved in innovative activity.

At that moment Ukraine has a lot of problems like corruption, dishonest courts, low level of social responsibility and etc. These facts repel foreign investors. There are several possible changes that can help make a difference:

1. The government should create an attractive economic environment for new companies (such as lower taxes for start-ups, tax holidays, free land for building new enterprises and etc.). If they will do it, country meets an increased interest from foreign investors.

2. The government should revise the investments structure. It means that capital should not be invested to the obsolete production areas like ferrous metallurgy and etc. These resources should be invested to the modern and future technologies (such as IT, bio- and nanotechnology and other).

Nowadays, under the conditions of the economy transformation towards social orientation, there is a transition from obsolete enterprise potential management forms to the new management capacity quality management. This will make highlight the main approaches to the quality of management capacity at modern enterprises:

1. Personnel potential reserve formation, which enables personnel selection.

2. Competition on the labor market, which results in the necessity of constant market research as well as research into its infrastructure and forecast.

3. Decrease in investment activity to provide for the survival of present-day businesses, which explains the need in highly skilled management elite.

4. High dynamics of entrepreneurial activity dictates new requirements to the managerial staff, thus it is necessary to upgrade skills.

The primary aim of management potential innovative development is provision of enterprise functional and production systems with the necessary number of workers with the appropriate qualification. In its turn, along with the change in the approach towards innovations, there is the change in the basic principles, provisions and standards of staff performance. However, under any conditions, provision of the high quality of management potential innovative development is one of the basic factors of enterprise efficiency and competitiveness.

The primary need is to focus on the set of measures necessary to provide for the management potential innovative development at a modern enterprise. of management potential innovative development measures must be elaborated at three stages:

1. Elaboration of the basic principles of innovative development.

2. Formation of overall enterprise policy on the basis of organizational and staffing policy (planning the need in management resources, reserve formation, staff formation), information policy (formation and support of the management potential information support system), economic policy (funds allocation principles and management staff efficiency), management staff development policy (elaboration of the sustainable management staff development program).

3. Performance and management potential development efficiency assessment for further elaboration of measures aimed at changing innovative development principles. 
In the process of elaborating the measures of management potential innovative development it is worth taking into account external and internal factors influencing directly this potential. The basic rule of forming this system of measures must lie the fact that the company policy in the sphere of management potential efficiency enhancement is the component of the overall company policy, but it is necessary to control the balance between the economic performance and social equity.

Modern enterprises achieve innovative development only under the condition of the availability of certain potena tial, management potential in particular. It is worth noting that the staff component is of great importance, i.e. personnel have become the main resource. However, complex systemic approach remains essential. In the process of studying the overall category of "innovative development potential", scholars distinguish the set of interrelated resources and capabilities of their implementation, which define its capacity (intellectual, technological, information, research, economic etc.) to balance internal development opportunities against external ones on the basis of constant search, exploitation and development of new spheres and means of effective current and potential market opportunities implementation (Kibalyuk, 2006).

The basic characteristic feature of management potential innovative development at a modern enterprise (Figure 4) is the necessity to conduct a set of additional measures aimed at adjusting to the current changing environment including wage and labor promotion policy formation, motivation, marketing in the sphere of management personnel, setting enterprise strategic aims and labor policy aims.

Currently, the management potential of a modern enterprise must meet the following requirements and, correspondingly, solve the given tasks:

1. Are all the available enterprise resources fully used? It is necessary to update the list of its resources, updating and broadening it at the expense of potential (possible) resources and its capabilities.

2. Are there any weaknesses in the resource utilization system? It is necessary to monitor effective resource utilization at an enterprise and regularly reappoint controllers responsible for the resources and results of their implementation.

3. Is innovative development characteristic of the enterprise? It is necessary to implement modern trends and peculiarities of the correspondent economic sphere development.

4. Is the system of staff activity adaptation to the changing economic (operating) conditions applied at an enterprise? Periodic application of mitigation means, techniques and methods of management and other staff adaptation to the changes in the economic conditions, which considerably facilitate implementation of changes and foster innovative development at modern enterprises.

Maximum absolute use of the available enterprise resources as well as the availability of the innovative development focus enable the organization to tap its resources efficiently and gain competitive advantage in the industry in accordance with the enterprise business activity as well as discover new (accompanying) business activities for the enterprise development and activity diversification, eliciting staff potential, which must be the primary task of management personnel at a modern enterprise and fully complies with the innovative development components.

The main problem of the management system of modern enterprises in the process of management potential innovative development is the under run of data updates in accordance with the needs of the economic activity and, primarily, the difficulty of implementing innovations at enterprises due to the lack of funds, time and willingness of both employees and managers.

According to Sabadyrjova (2010), enterprise management potential is the aggregate of interrelated resource system features, management process opportunities and their marshaling under the conditions of enterprise innovative development in order to gain competitive advantage with account taken of the external environment. When studying management potential features, it is worth paying attention to the variables that impact considerably on the enterprise activity (Mazhnik, \& Novikova, 2015; Sabadyrova, 2010; Fernandez-Araoz, Roscoe, \& Aramaki, 2017). 


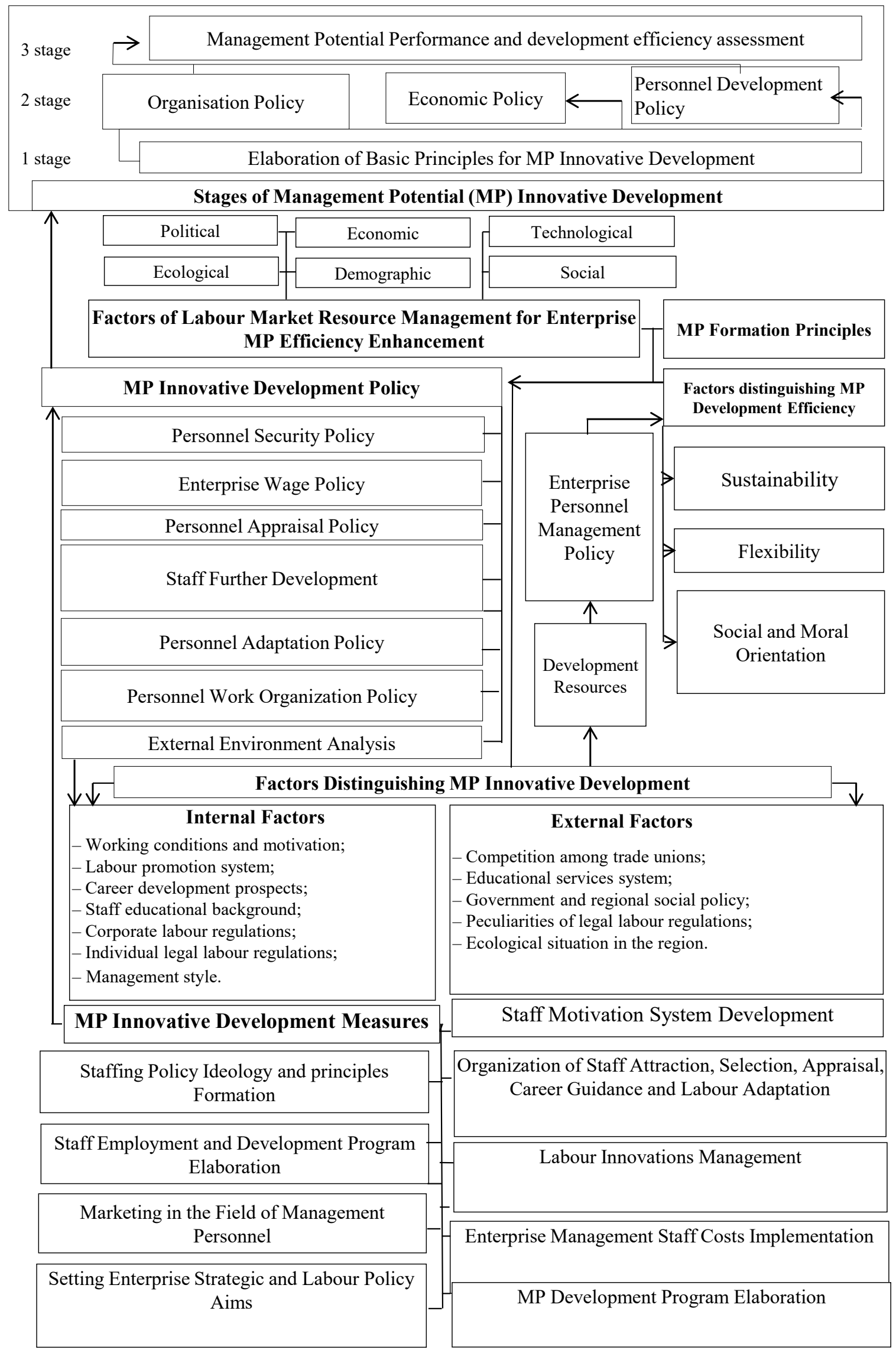


Stability of the external environment of enterprise functioning (see Figure 4 for external factors, namely macron economic, social, demographic, social norms and standards etc.) that accounts for incoming and outgoing information in the management system.

The results of the research allow to state that the issues of the managerial capacity development of a modern enterprise considered in the article are relevant. The essence distinguished in the article and the basic structure of management potential innovative development measures at a modern enterprise will enable to forecast the main trends of changes in impact factors and achieve the most efficient management potential development by focusing on expanding potential resources and the efficiency of their use. The identified patterns of influence of financing parameters in terms of its individual sources on the dynamics of the total expenditure of domestic enterprises on innovation allow to specify the problem areas in the context of the necessary efforts and allocate available resources of the national economy.

Effective use of managerial capacity, its constant development possible only in the presence of a modern managen ment system with such an important characteristic as the strategic aspect of resource planning. The additional measures of management capacity development proposed in the research, solves the issue of lagging behind the process of updating data in accordance to the needs of economic activity and complexity of implementing innovations in enterprises.

The issue of organizational characteristics forming of managerial capacity and the ability to mobilize explicit and latent competencies to ensure competitiveness, stable operation and continuous development under the current conditions is subject to further research.

\section{AUTHORS CONTRIBUTIONS}

Conceptualization: Pysmak Viktoriia.

Data curation: Sigaieva Tetiana.

Funding acquisition: Mazhnyk Lidiya.

Investigation: Pysmak Viktoriia, Mazhnyk Lidiya.

Resources: Mazhnyk Lidiya, Sigaieva Tetiana.

Software: Sigaieva Tetiana.

Validation: Mazhnyk Lidiya.

Writing - original draft: Pysmak Viktoriia, Sigaieva Tetiana.

Writing - review \& editing: Pysmak Viktoriia.

\section{REFERENCES}

1. Anim-Yeboah, S., Boateng, R., Odoom, R., \& Kolog, E. (2020). Digital Transformation Process and the Capability and Capacity Implications for Small and Medium Enterprises. International Journal of E-Entrepreneurship and Innovation, 10(2), 26-44. Retrieved from https://www.igi-global.com/gateway/article/253873

2. Armstrong, M., \& Taylor, S. (2020). Armstrong's Handbook of Human Resource Management Practice (800 p.). United Kingdom: Kogan. Retrieved from https://www.koganpage.com/product/armstrong-s-handbook-of-human-resource-management-practice9780749498276\#: :text=Reviews\%20Supporting\%20resources-,About\%20the\%20book,the\%20needs\%20of\%20the\%20business.

3. Bilorus, T. (2018). Development strategy formation of the personnel management system of the enterprise based on portfolio analysis. Marketing and Management of Innovations, 1, 184-195. (In Ukrainian). http://doi.org/10.21272/mmi.2018.1-13

4. Busel, V. (Ed.) (2016). Velykyi tlumachnyi slovnyk ukrainskoi movy [Large explanatory dictionary of the Ukrainian language]. Irpin: VTF «Perun». (In Ukrainian)

5. Fernandez-Araoz, C., Roscoe, A., \& Aramaki, K. (2017). Turning Potential into Success: The Missing Link in Leadership Development. Harward Business Review, November-December, 86-93. Retrieved from https://hbr.org/2017/11/turning-potential-into-success-themissing-link-in-leadership-development

6. Hruzinova, L. (2010). Upravlencheskiy potentsial kak element ekonomicheskogo potentsiala promyshlennogo predpriyatiya [Management potential as an element of the economic potential of an industrial enterprise]. Prometey - Prometheus, 3(33), 156-158. (In Russian)

7. Hruzinova, L. (2010). Upravlinski komunikatsii i potentsial systemy upravlinnia promyslovym pidpryiemstvom [Management communications and the potential of the industrial enterprise management system]. Visnik of the volodymyr dahl east ukrainian national university, 12(2), 250-253. (In Ukrainian) 
8. Kibalyuk, I. (2006). Postroyeniye effektivnoy kadrovoy politiki kak osnova optimizatsii kadrovykh resursov sovremennoy organizatsii [Building an effective personnel policy as the basis for optimizing the human resources of a modern organization]. Nauka i obrazovaniye. Novyye tekhnologii, 1, 75-79. (In Russian)

9. Ladunka, I. (2011). Vprovadzhennia intehralnoi otsinky konkurentnykh perevah upravlinskoho personalu [Introduction of integrated assessment of competitive advantages of management staff]. State and regions. Series: Economics and Business, 3, 140-143. (In Ukrainian)

10. Mazhnik, L., \& Novikova, M. (2015). Tekhnolohiia upravlinnia personalom: teoretychni ta metodychni aspekty [Personnel management technology: theoretical and methodological aspects]. Kharkiv: KhNAMGh. (In Ukrainian)

11. Pysarenko, T., Kvasha, T., Rozhkova, L., \& Kovalenko, O. (2020). Innovatsiina diialnist v Ukraini u 2019 rotsi: naukovo-analitychna dopovid [Innovation activity in Ukraine in 2019: scientific and analytical report] (45 p.). Kyiv: UkrINTEI. (In Ukrainian). Retrieved from https:// mon.gov.ua/storage/app/media/innovatsii-transfer-tehnologiy/2020/08/za-2019-1-1.pdf

12. Sabadyrova, A. (2010). Teoretychni osnovy upravlinskoho potentsialu promyslovoho pidpryiemstva [Theoretical bases of managerial potential of industrial enterprise]. Herald of Khmelnytskyi national university. Economic Sciences, 2(5), 83-88. (In Ukrainian). Retrieved from http://dspace.oneu.edu.ua/jspui/handle/123456789/443

13. State Statistics Service of Ukraine (n.d.). Ekonomichna statystyka / Nauka, tekhnolohii ta innovatsii [Economic statistics / Science, technology and innovation]. (In Ukrainian). Retrieved from http://www.ukrstat.gov.ua/operativ/menu/menu_u/ni.htm

14. State Statistics Service of Ukraine (n.d.). Innovatsiina diialnist promyslovykh pidpryiemstv Ukrainy 2010-2015 rr. [Innovative activity of industrial enterprises of Ukraine in 2010-2015]. (In Ukrainian). Retrieved from http://www.ukrstat.gov.ua

15. Vorsovskyi, O. (2007). Teoretyko-metodychni osnovy investytsiinoho potentsialu pidpryiemstv [Theoretical and methodological bases of investment potential of enterprises]. Investments: practice and experience - Investytsiyi: praktyka ta dosvid, 15, 8-11. (In Ukrainian)

16. Yastremska, O. (Ed.) (2014). Upravlinnia zhyttiediialnistiu pidpryiemstv promyslovosti [Management of vital activity of industrial enterprises] (432 p.). Kharkiv: KhNEU im. S. Kuznetsia. (In Ukrainian). Retrieved from http://www.repository.hneu.edu.ua/handle/123456789/9730 